\title{
Role of p16 deletion and Bmi1 copy number variation in glioma
}

\author{
GK Chetan ${ }^{1 *}$, M K Sibin', Dhananjaya I Bhat ${ }^{2}$, Ch Lavanya $^{1}$, Manoj M Jeru', N Geethashree ${ }^{1}$ \\ From International Conference on Human Genetics and 39th Annual Meeting of the Indian Society of \\ Human Genetics (ISHG) \\ Ahmadabad, India. 23-25 January 2013
}

\section{Background}

Malignant gliomas are the most common and lethal intracranial tumors. Glioma exhibit a relentless malignant progression characterized by widespread invasion throughout the brain, resistance to traditional and newer targeted therapeutic approaches. The classical genetic alterations in glioma target pathways governing cellular proliferation, cellular survival (apoptosis and necrosis), invasion, and angiogenesis. The p16 is the second most altered tumor suppressor gene and frequent mutations and deletions of p16 in human cancer cell lines first suggested an important role for p16 in carcinogenesis. The $\mathrm{Bmi}-1$ is an important oncogene and its expression is found to be elevated in many types of cancers. Role of Bmi1 copy number variation in glioma is still under debate. In this study we analyzed the alterations in p16 and Bmi1 genes in glioma.

\section{Material and methods}

50 glioma samples from patients were collected from the neurosurgery OT. Tissues having $>95 \%$ tumor cells were processed and DNA was isolated. For the analysis of p16 deletion multiplex PCR was done using primers specific for all 3 exons of p16. Copy number variation in Bmil gene was analyzed using real time PCR with Bmi1 specific primers.

\section{Results}

Our results showed that there is $20 \%$ of p16 deletion in our samples and the deletion pattern vary with exons. There was no copy number variation found in Bmi1 gene in glioma.

\footnotetext{
* Correspondence: drchetangk@gmail.com

'Department of Human genetic, National Institute of Mental Health and neurosciences, Hosur road, Bangalore-29, India

Full list of author information is available at the end of the article
}

\section{Conclusions}

We concluded that the p16 deletion is a common alteration found in glioma and Bmil gene amplification is not the common mechanism to increase the expression of this protein in glioma.

\section{Authors' details \\ ${ }^{1}$ Department of Human genetic, National Institute of Mental Health and neurosciences, Hosur road, Bangalore-29, India. ${ }^{2}$ Department of Neurosurgery, National Institute of Mental Health and neurosciences, Hosur road, Bangalore-29, India.}

Published: 21 January 2014

doi:10.1186/1755-8166-7-S1-P11

Cite this article as: Chetan et al:: Role of p16 deletion and Bmi1 copy number variation in glioma. Molecular Cytogenetics 2014 7(Suppl 1):P11.

\section{Submit your next manuscript to BioMed Central and take full advantage of: \\ - Convenient online submission \\ - Thorough peer review \\ - No space constraints or color figure charges \\ - Immediate publication on acceptance \\ - Inclusion in PubMed, CAS, Scopus and Google Scholar \\ - Research which is freely available for redistribution

